\title{
Effects of prepartum 2,4-thiazolidinedione on metabolism and performance in transition dairy cows
}

\author{
K. L. Smith, ${ }^{1}$ W. R. Butler, and T. R. Overton ${ }^{2}$ \\ Department of Animal Science, Cornell University, Ithaca, NY 14853
}

\begin{abstract}
Thiazolidinediones (TZD) are potent synthetic ligands for peroxisome proliferator-activated receptor- $\gamma$ that have been shown previously to reduce plasma nonesterified fatty acids and increase peripartal dry matter intake (DMI) in dairy cows. Data from Holstein cows $(n=36)$ entering their second or greater lactation were used to determine whether late prepartum administration of TZD would affect periparturient metabolism, milk production, and ovarian activity. Cows were administered $0,2.0$, or $4.0 \mathrm{mg}$ of $\mathrm{TZD} / \mathrm{kg}$ of $\mathrm{BW}$ by intrajugular infusion once daily from $21 \mathrm{~d}$ before expected parturition until parturition. Plasma samples were collected daily from $22 \mathrm{~d}$ before expected parturition through $21 \mathrm{~d}$ postpartum and twice weekly from wk 4 through 9 postpartum. In response to increasing TZD dosage, plasma nonesterified fatty acid concentrations decreased linearly during the postpartum period (d 0 to $+21: 348,331,268 \pm 31 \mu \mathrm{Eq} / \mathrm{L}$, respectively). Plasma concentrations of glucose were highest in cows administered $4.0 \mathrm{mg}$ of $\mathrm{TZD} / \mathrm{kg}$ of $\mathrm{BW}$ during the peripartum and postpartum periods ( $\mathrm{d}-7$ to $+7: 57.9$, $57.8,61.1 \pm 0.8 \mathrm{mg} / \mathrm{dL}$ and $\mathrm{d} 0$ to $+21: 51.6,49.3,54.7$ $\pm 1.1 \mathrm{mg} / \mathrm{dL}$, respectively). Plasma concentrations of $\beta$-hydroxybutyrate were increased during the peripartum period by TZD administration $(9.6,9.9,10.2 \pm 0.3$ $\mathrm{mg} / \mathrm{dL}$ ) but were not affected during the postpartum period. Plasma insulin was not affected by treatment during any time period. Postpartum liver triglyceride content was decreased linearly $(11.0,10.4,4.2 \pm 1.6 \%)$ and glycogen content was increased linearly $(2.16,2.38$, $2.79 \pm 0.19 \%)$ by prepartum TZD administration. Prepartum TZD administration linearly increased DMI during the peripartum period ( $\mathrm{d}-7$ to $+7: 16.1,17.2$, $17.3 \pm 0.5 \mathrm{~kg} / \mathrm{d}$ ). Cows administered TZD prepartum maintained higher postpartum body condition scores than control cows (wk 1 through 9: 2.77, 2.89, $3.02 \pm$

Received July 1, 2008.

Accepted March 31, 2009.

${ }^{1}$ Current address: Elanco Animal Health, 2001 W. Main St., Greenfield, IN 46140.

${ }^{2}$ Corresponding author: tro $2 @$ cornell.edu
\end{abstract}

0.05). There was no effect of prepartum TZD on milk yield; however, yields of $3.5 \%$ fat-corrected milk (52.2, $54.6,48.0 \pm 1.6 \mathrm{~kg} / \mathrm{d}$ ) and most other milk components were decreased in cows that received $4.0 \mathrm{mg}$ of TZD/ $\mathrm{kg}$ of BW prepartum. Prepartum TZD administration linearly decreased the number of days to first ovulation $(29.3,28.3,19.0 \pm 3.6 \mathrm{~d})$. These results suggest that prepartum administration of TZD improves metabolic health and DMI of periparturient dairy cows and may decrease reliance on body fat reserves during early lactation.

Key words: transition cow, thiazolidinedione, peroxisome proliferator-activated receptor- $\gamma$

\section{INTRODUCTION}

It is well recognized that dairy cows undergo important metabolic adaptations during late pregnancy to support fetal nutrient demands and at the onset of lactation to support milk production. These homeorhetic adaptations involved in the regulation of nutrient and energy partitioning during late pregnancy and early lactation occur in a variety of target tissues, and typically involve changes in responses to homeostatic signals such as insulin and epinephrine (Bauman and Currie, 1980; Bell, 1995). Changes in the periparturient cow that relate to energy metabolism include a large increase in glucose demand by the mammary gland, which is supported by a decrease in oxidation of glucose by peripheral tissues (Bauman and Elliot, 1983) and an increase in glucose output by the liver (Reynolds et al., 2003); mobilization of body fat to meet overall energy demands is supported by a decrease in the response of adipose tissue to insulin (Petterson et al., 1993, 1994). These changes in skeletal and adipose tissue during the prepartum period result from homeorhetic controls that facilitate insulin resistance (Bell, 1995; Smith, 2004). The net result of these adaptations is coordinated support of fetal needs and subsequent high milk production in the face of decreasing and eventually insufficient DMI during late pregnancy and early lactation.

Adipose tissue is a metabolically dynamic endocrine organ, and adipose tissue metabolism in the transition dairy cow has received some attention (as reviewed by 
Vernon, 2005), but most research has focused on the utilization of fatty acids (NEFA) that have already been mobilized and taken up by the liver (Drackley et al., 2001). In early lactation, adipose tissue is predisposed to catabolism through increased lipolysis and decreased lipogenesis (McNamara, 1991). Insulin resistance contributes to these processes to mitigate the period of negative energy balance that occurs because the postpartum increase in energy intake lags behind the increase in milk energy output. Recently, it was reported that insulin resistance can be induced by experimental hyperlipidemia, and the periparturient dairy cow that mobilizes excessive amounts of body fat is at greater risk for insulin resistance, leading to energyrelated metabolic disorders (Pires et al. 2007).

Insulin resistance is likely mediated through the actions of peroxisome proliferator-activated receptor- $\gamma$ (PPAR- $\gamma)$ that is highly expressed in bovine adipose tissue (Sundvold et al., 1997; Harvatine and Bauman, 2007). Peroxisome proliferator-activated receptor- $\gamma$ belongs to a subfamily of the nuclear-receptor family that regulates gene expression in response to ligand binding (Hammarstedt et al., 2005). Activation of PPAR- $\gamma$ potentiates adipocyte differentiation, enhances insulin action, and decreases the release of FFA from the adipocytes (Houseknecht et al., 2002; Guo and Tabrizchi, 2006). The thiazolindinediones (TZD) are the most potent ligands of PPAR- $\gamma$ (Houseknecht et al., 2002). In addition to the effects of TZD on adipose tissue, there have been numerous reports on its beneficial effects on inflammation and its antiinflammatory properties (Hammarstedt et al., 2005).

Limited research has been conducted using TZD in ruminants. Kushibiki et al. (2001) reported that administering TZD to steers after a challenge with tumor necrosis factor- $\alpha$ (TNF- $\alpha)$ to induce insulin resistance resulted in decreased plasma NEFA. Recently, we demonstrated that administration of 2,4-thiazolidinedione during the late prepartum period in dairy cows tended to reduce the dramatic increase in plasma NEFA at the time of calving and during the immediate postpartum period and also tended to increase peripartal DMI (Smith et al., 2007). The objectives of this study were to study more comprehensively the role of TZD administration on metabolism and subsequent performance of transition dairy cows and to determine whether these responses of cows to prepartum administration of TZD are dose dependent.

\section{MATERIALS AND METHODS}

\section{Animals, Treatments, and Sampling}

All procedures involving animals were approved before the onset of the experiment by the Cornell Uni- versity Institutional Animal Care and Use Committee, and the experiment commenced in September 2006 and ended in March 2007. Holstein cows $(\mathrm{n}=40)$ entering their second or later lactation that had been dried off at $60 \mathrm{~d}$ before expected calving were selected from the Cornell Teaching and Research Center dairy herd and moved to individual tie stalls at approximately $32 \mathrm{~d}$ before expected parturition.

Cows were fitted with an indwelling jugular catheter (Micro-Renathane Implantation Tubing, $2.03 \mathrm{~mm}$ o.d. $\times 1.02 \mathrm{~mm}$ i.d.; Braintree Scientific Inc., Braintree MA) on d 23 before expected parturition. Beginning on d 21 before expected parturition, cows were assigned to 1 of 3 treatments in a completely randomized design and were administered either TZD (2.0 or $4.0 \mathrm{mg} / \mathrm{kg}$ of BW) or saline (control) by intrajugular infusion once daily at $1200 \mathrm{~h}$. Daily administration of treatments continued until parturition and actual days on treatment averaged $20 \pm 4,22 \pm 5$, and $20 \pm 4 \mathrm{~d}$, respectively, for the 3 increasing doses of TZD. The TZD was obtained as 2,4-thiazolidinedione from Sigma Chemical Co. (St. Louis, MO). All treatments were administered in 100 $\mathrm{mL}$ of sterile saline; the TZD was dissolved into sterile saline on a daily basis, left overnight in the dark at room temperature and allowed to dissolve, and gently mixed before drawing into sterile syringes. Cow assignment to treatments was balanced for BCS and calculated previous 305-d mature-equivalent milk yield.

Cows were fed a common TMR for ad libitum intake during the pre- and postpartum periods that was formulated to meet or exceed predicted requirements for energy, protein, minerals, and vitamins (NRC, 2001). Individual DMI was recorded from $32 \mathrm{~d}$ before expected parturition through $63 \mathrm{~d}$ postpartum. Ingredient and chemical compositions of the diets fed during the experiment are described in Table 1. All nonforage ingredients in both prepartum and postpartum TMR diets were blended by a commercial feed mill into separate concentrate mixtures and were mixed at the farm with the appropriate forage components for each diet. Fresh feed was provided each morning at $0900 \mathrm{~h}$, orts were weighed and recorded daily, and water was made available at all times.

Samples of the forages, concentrate mixtures, and TMR were obtained weekly throughout the experiment, and DM content was determined by drying at $55^{\circ} \mathrm{C}$ until a static weight. Amounts of individual feed components in the TMR were adjusted weekly based on changes in the DM content of these feed components. Dry matter contents of the TMR were used in calculating DMI for the corresponding week. The weekly TMR samples were composited into 4 -wk composite samples and submitted $(\mathrm{n}=4$ for prepartum TMR, and $\mathrm{n}=5$ for postpartum TMR) to a commercial laboratory for 
Table 1. Ingredient and chemical composition (DM basis) of prepartum and postpartum diets

\begin{tabular}{|c|c|c|}
\hline Item & $\begin{array}{l}\text { Prepartum } \\
\text { diet }\end{array}$ & $\begin{array}{l}\text { Postpartum } \\
\text { diet }\end{array}$ \\
\hline \multicolumn{3}{|l|}{ Ingredient, $\%$} \\
\hline Corn silage, processed & 38.3 & 29.6 \\
\hline Alfalfa silage & 17.1 & 24.2 \\
\hline Wheat straw & 12.1 & \\
\hline Ground shelled corn & - & 13.9 \\
\hline Corn germ meal & 10.0 & 5.9 \\
\hline Distillers grains (with solubles) & 10.0 & 5.3 \\
\hline Soybean meal & 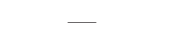 & 4.5 \\
\hline Soybean hulls & 0.47 & 2.6 \\
\hline Canola meal & 1.10 & 2.2 \\
\hline Citrus pulp & 2.60 & 2.2 \\
\hline Expeller soybean meal & - & 2.0 \\
\hline Blood meal (flash-dried) & 0.17 & 1.05 \\
\hline Sugar & 1.60 & 0.90 \\
\hline Wheat middlings & 2.70 & 0.90 \\
\hline Cereal trailings & - & 0.85 \\
\hline Energy Booster $100^{1}$ & - & 0.81 \\
\hline Calcium carbonate & 0.80 & 0.80 \\
\hline Vitamin-mineral premix ${ }^{2}$ & 0.37 & 0.54 \\
\hline Sodium bicarbonate & - & 0.43 \\
\hline Salt & - & 0.34 \\
\hline Tallow (beef) & - & 0.31 \\
\hline Yeast culture $^{3}$ & 0.30 & . \\
\hline Urea & — & 0.20 \\
\hline Magnesium oxide & 0.27 & 0.13 \\
\hline Dicalcium phosphate & 0.01 & 0.10 \\
\hline Magnesium sulfate & - & 0.10 \\
\hline Cane molasses & 1.30 & 0.06 \\
\hline Smartamine $\mathrm{M}^{4}$ & & 0.03 \\
\hline Trace mineral premix ${ }^{5}$ & 0.05 & 0.02 \\
\hline Availa $4^{6}$ & 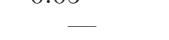 & 0.01 \\
\hline Sel-Plex- $2000^{7}$ & 0.01 & 0.01 \\
\hline Vitamin A, D, and E premix ${ }^{8}$ & 0.02 & 0.01 \\
\hline Calcium sulfate & 0.70 & 0.009 \\
\hline Mepron M85 ${ }^{9}$ & - & 0.004 \\
\hline Rumensin ${ }^{10}$ & 0.01 & - \\
\hline Vitamin E premix ${ }^{11}$ & 0.02 & 0.001 \\
\hline \multicolumn{3}{|l|}{ Chemical composition $( \pm \mathrm{SD})^{12}$} \\
\hline $\mathrm{NE}_{\mathrm{L}},{ }^{13} \mathrm{Mcal} / \mathrm{kg}$ & $1.60(0.03)$ & $1.69(0.02)$ \\
\hline $\mathrm{CP}, \%$ & $14.8(0.2)$ & $19.0(0.6)$ \\
\hline Acid detergent insoluble CP, $\%$ & $0.8(0.2)$ & $1.1(0.09)$ \\
\hline Neutral detergent insoluble CP, \% & $2.2(0.5)$ & $3.2(0.3)$ \\
\hline $\mathrm{ADF}, \%$ & $27.8(1.6)$ & $22.5(0.9)$ \\
\hline NDF, $\%$ & $44.4(1.7)$ & $34.4(0.7)$ \\
\hline Starch, \% & $18.2(2.3)$ & $23.6(0.9)$ \\
\hline $\mathrm{NFC},{ }^{14} \%$ & 32.2 & 37.3 \\
\hline Ether extract, \% & $3.4(0.6)$ & $4.8(0.3)$ \\
\hline Ash, $\%$ & $7.5(0.4)$ & $7.7(0.2)$ \\
\hline $\mathrm{Ca}, \%$ & $0.99(0.06)$ & $1.09(0.04)$ \\
\hline $\mathrm{P}, \%$ & $0.41(0.01)$ & $0.41(0.01)$ \\
\hline $\mathrm{K}, \%$ & $1.71(0.10)$ & $1.82(0.15)$ \\
\hline
\end{tabular}

Continued

wet chemistry analysis (Dairy One Cooperative Inc., Ithaca, NY) for DM, CP, ADF, NDF, neutral detergent insoluble $\mathrm{CP}$, acid detergent insoluble $\mathrm{CP}$, ether extract, ash, starch, and macro- and microminerals as described previously (Smith et al., 2007).

Body weights and BCS of each animal were recorded once weekly beginning the week before treatment initiation and continuing throughout the study. Body condi-
Table 1 (Continued). Ingredient and chemical composition (DM basis) of prepartum and postpartum diets

\begin{tabular}{lcc}
\hline Item & $\begin{array}{c}\text { Prepartum } \\
\text { diet }\end{array}$ & $\begin{array}{c}\text { Postpartum } \\
\text { diet }\end{array}$ \\
\hline $\mathrm{Mg}, \%$ & $0.37(0.03)$ & $0.31(0.02)$ \\
$\mathrm{Na}, \%$ & $0.13(0.06)$ & $0.37(0.05)$ \\
$\mathrm{Cl}, \%$ & $0.37(0.11)$ & $0.46(0.05)$ \\
$\mathrm{S}, \%$ & $0.31(0.02)$ & $0.26(0.02)$ \\
$\mathrm{DCAD},{ }^{15} \mathrm{mEq} / 100 \mathrm{~g}$ of $\mathrm{DM}$ & 19.6 & 33.4 \\
\hline
\end{tabular}

${ }^{1}$ Prilled saturated FFA, MS Specialty Nutrition, Dundee, IL.

${ }^{2}$ Contained $36 \% \mathrm{Ca}, 0.009 \% \mathrm{P}, 0.949 \% \mathrm{Mg}, 0.839 \% \mathrm{~S}, 1,274 \mathrm{mg} / \mathrm{kg}$ of $\mathrm{Cu}, 6,040 \mathrm{mg} / \mathrm{kg}$ of Mn, $165 \mathrm{mg} / \mathrm{kg}$ of Co, $128 \mathrm{mg} / \mathrm{kg}$ of I, $7,371 \mathrm{mg} /$ $\mathrm{kg}$ of $\mathrm{Zn}, 1,204 \mathrm{IU} / \mathrm{kg}$ of vitamin A, $225 \mathrm{IU} / \mathrm{g}$ of vitamin D, and 2,305 $\mathrm{IU} / \mathrm{kg}$ of vitamin $\mathrm{E}$.

${ }^{3}$ Cargill Animal Nutrition proprietary blend, Elk River, MN.

${ }^{4}$ Rumen-protected methionine ( $>70 \%$ DL-methionine, wt/wt), Adisseo USA, Alpharetta, GA.

${ }^{5}$ Contained $112,255 \mathrm{mg} / \mathrm{kg}$ of $\mathrm{Zn}, 19,388 \mathrm{mg} / \mathrm{kg}$ of $\mathrm{Cu}, 91,837 \mathrm{mg} / \mathrm{kg}$ of $\mathrm{Mn}, 2,551 \mathrm{mg} / \mathrm{kg}$ of $\mathrm{Co}$, and $1,939 \mathrm{mg} / \mathrm{kg}$ of I.

${ }^{6}$ Combination of zinc, copper, manganese, and cobalt; Zinpro Animal Nutrition Inc., Eden Prairie, MN.

${ }^{7}$ Selenium yeast, Alltech Inc., Nicholasville, KY.

${ }^{8}$ Contained $37,113 \mathrm{IU} / \mathrm{kg}$ of vitamin $\mathrm{A}, 7,216 \mathrm{IU} / \mathrm{kg}$ of vitamin $\mathrm{D}$, and $72,165 \mathrm{IU} / \mathrm{kg}$ of vitamin $\mathrm{E}$.

${ }^{9}$ Rumen-protected methionine (85\% DL-methionine, wt/wt), Degussa Corporation, Kennesaw, GA.

${ }^{10}$ Contained $176 \mathrm{~g} / \mathrm{kg}$ of monensin sodium, Elanco Animal Health, Greenfield, IN.

${ }^{11}$ Contained 500,444 IU/kg of vitamin E.

${ }^{12}$ Based on 4 composite samples of prepartum TMR and 5 composite samples of postpartum TMR

${ }^{13}$ Calculated by Dairy One Cooperative (Ithaca, NY) using NRC (2001) equations and using a $3 \times$ maintenance discount for the postpartum period and a $1.5 \times$ maintenance discount for the prepartum period.

${ }^{14}$ Calculated as $100-[(\mathrm{NDF}-\mathrm{NDFCP})+\mathrm{CP}+$ ash + ether extract $]$ (NRC, 2001).

${ }^{15}$ Calculated as $\mathrm{mEq}[(\mathrm{Na}+\mathrm{K})-(\mathrm{Cl}+\mathrm{S})] / 100 \mathrm{~g}$ of DM (NRC, 2001).

tion scores were assigned using a 5-point system (Wildman et al., 1982) by 2 individuals blinded to treatment and the average of these 2 scores was the assigned value. Energy balance was calculated as net energy balance during both the prepartum and postpartum periods using NRC (2001) equations. Prepartum calculations of net energy requirements were based on BW, actual calf birth weight, and day of pregnancy. Postpartum calculations of net energy requirements were based on BW, milk yield, and milk composition (fat, true protein, and lactose). Daily observations, daily rectal temperatures, and general health records were maintained throughout the study.

After parturition, cows were milked 3 times daily (0800, 1600, and $2400 \mathrm{~h}$ ) and yields were recorded at each milking for the first $63 \mathrm{~d}$ postpartum. During the 9-wk postpartum period, milk samples were collected from each milking on $1 \mathrm{~d} /$ wk and composited on an equal volume basis into a single sample for analysis. 
The composited samples were stored at $4^{\circ} \mathrm{C}$ with a preservative (Bronopol tablet; D\&F Control System, San Ramon, CA) until analyzed (Dairy One Cooperative Inc., Ithaca, NY) within $24 \mathrm{~h}$ for fat, protein, and lactose using infrared analysis and SCC by an optical fluorescent method as described previously (Smith et al., 2007).

\section{Plasma and Tissue Sampling and Analyses}

Blood samples were collected immediately before treatment administration at $1200 \mathrm{~h}$ via the jugular catheter on d 22 (covariate) and then daily from d 21 before expected parturition until parturition. A sterile solution of sodium heparin (200 IU/mL of saline) and Naxcel (4 mg/mL of saline; Pfizer Inc., New York, NY) was injected into the catheter after sampling to prevent blood coagulation and bacterial growth. After parturition, blood samples were collected daily beginning at $1200 \mathrm{~h}$ via venipuncture of the coccygeal vessels until $21 \mathrm{~d}$ postpartum and then twice per week from wk 4 through 9 postpartum. Blood samples were transferred into glass test tubes containing sodium heparin (100 $\mathrm{IU} / \mathrm{mL}$ of blood). Plasma was harvested after centrifugation $\left(2,800 \times g\right.$ for $15 \mathrm{~min}$ at $\left.4^{\circ} \mathrm{C}\right)$, snap-frozen in liquid $\mathrm{N}_{2}$, and stored at $-20^{\circ} \mathrm{C}$ until analyses for metabolites. Plasma concentrations of glucose were determined by enzymatic analysis (glucose oxidase) using a commercial kit (kit no. 510-A; Sigma Chemical). Plasma concentrations of NEFA were analyzed by enzymatic analysis (NEFA-C; Wako Pure Chemical Industries, Osaka, Japan). Plasma concentrations of BHBA were determined by enzymatic analysis (BHBA dehydrogenase; kit no. 310, Sigma Chemical). All spectrophotometric measurements were conducted using a Versa $_{\max }$ tunable microplate reader (Molecular Devices, Sunnyvale, CA).

Plasma was analyzed for concentrations of insulin by RIA (Ehrhardt et al., 2001) using bovine insulin (Elanco Animal Health, Greenfield, IN) for iodination and standards (the lowest standard was $0.05 \mathrm{ng} / \mathrm{mL}$ ). Intra- and interassay CV for the insulin RIA were 12.5 and $13.3 \%$, respectively. Finally, plasma was analyzed for concentrations of progesterone by RIA (Staigmiller et al., 1979; Nara and First, 1981). Intra- and interassay CV for the progesterone RIA were 8.5 and $8.1 \%$, respectively. Plasma progesterone concentrations were used to determine days to first ovulation. Ovulation was assumed to have occurred $3 \mathrm{~d}$ before measured plasma progesterone was greater than or equal to $1 \mathrm{ng} / \mathrm{mL}$.

Liver samples were obtained from each cow via percutaneous trochar biopsy on d 10 and 21 postpartum. Briefly, the biopsy site at the 11th intercostal space was clipped and scrubbed using surgical scrub [Betadine
Surgical Scrub (7.5\% povidone-iodine); Purdue Frederick, Stamford, CT]. Cows were administered $20 \mathrm{mg}$ of the sedative xylazine hydrochloride (Rompun, $2 \%$; Bayer Inc., Sarnia, Ontario, Canada) via venipuncture of the coccygeal vessels $10 \mathrm{~min}$ before the procedure. A local anesthetic (Lidocaine-HCl, 2\%; Butler Animal Health, Dublin, $\mathrm{OH}$ ) was administered percutaneously; an incision (approximately $3 \mathrm{~cm}$ ) was made, and the liver was biopsied using a stainless steel biopsy tool (30 $\mathrm{cm}$ in length $\times 1 \mathrm{~cm}$ o.d.). After biopsy, the incision was closed using surgical staples (3M Precise Vista Disposable Skin Stapler; 3M, St. Paul, MN) and a topical antiseptic was applied (BluKote aerosol spray; H. W. Naylor Co., Morris, NY). Liver tissue was blotted to remove excess blood and connective tissue, snap-frozen in liquid $\mathrm{N}_{2}$, and stored at $-80^{\circ} \mathrm{C}$ until analyzed for triglyceride (TG) and glycogen content as described previously (Smith et al., 2007).

The first milking after calving was defined as colostrum. The milk was weighed and subsampled. Subsamples were immediately frozen and stored at $-20^{\circ} \mathrm{C}$ until analysis for total IgG using the Single Radial Immunodiffusion assay (Bethyl Laboratories Inc., Montgomery, TX). Samples were thawed at room temperature, thoroughly mixed by vortexing, diluted 1:4 with 0.05 $M$ phosphate buffer ( $1 \mathrm{~mL}$ of colostrum, $3 \mathrm{~mL}$ of PBS), and mixed by vortexing before plating diluted samples for analysis.

\section{Ovarian Ultrasonography}

Ovarian follicular activity of all cows was examined by linear array ultrasonography $(7.5-\mathrm{MHz}$ transrectal transducer, Aloka 210; Corometrics Medical Systems Inc., Wallingford, CT) 3 times weekly (Monday, Wednesday, and Friday) beginning on d 8 to 10 postpartum and continuing through $21 \mathrm{~d}$ postpartum. Diameter of the dominant follicles and corpora lutea between ultrasound examinations was calculated by linear interpolation.

\section{Statistical Analyses}

Before statistical analysis, 4 cows were removed from the data set. One cow was removed from the control group because she gave birth to twins, 1 cow was removed from the group administered $2.0 \mathrm{mg}$ of TZD/ $\mathrm{kg}$ of BW because she suffered a severe uterine torsion before calving, and 2 cows were removed from the group administered $4.0 \mathrm{mg}$ of $\mathrm{TZD} / \mathrm{kg}$ of $\mathrm{BW}$ because they gave birth to twins.

Pretreatment values for plasma variables and DMI, BW, and BCS measured or assessed during the week before assignment to treatments were used as covari- 
Table 2. Least squares means for the effects of prepartum thiazolidinedione (TZD) treatment on plasma metabolites, plasma insulin, and liver composition ${ }^{1}$

\begin{tabular}{|c|c|c|c|c|c|c|}
\hline \multirow[b]{2}{*}{ Item } & \multicolumn{3}{|c|}{$\mathrm{TZD},{ }^{2} \mathrm{mg} / \mathrm{kg}$ of $\mathrm{BW}$} & \multirow[b]{2}{*}{$\mathrm{SE}$} & \multicolumn{2}{|c|}{$P$-value } \\
\hline & 0 & 2.0 & 4.0 & & Linear & Quadratic \\
\hline \multicolumn{7}{|l|}{ NEFA, $\mu \mathrm{Eq} / \mathrm{L}$} \\
\hline Prepartum & 128 & 171 & 118 & 18 & 0.68 & 0.03 \\
\hline Postpartum & 348 & 331 & 268 & 31 & 0.04 & 0.48 \\
\hline Peripartum & 270 & 291 & 219 & 26 & 0.16 & 0.15 \\
\hline \multicolumn{7}{|c|}{ Glucose, mg/dL } \\
\hline Prepartum & 64.3 & 66.0 & 66.1 & 0.8 & 0.11 & 0.43 \\
\hline Postpartum & 51.6 & 49.3 & 54.7 & 1.1 & 0.03 & 0.003 \\
\hline Peripartum & 57.9 & 57.8 & 61.1 & 0.8 & 0.002 & 0.06 \\
\hline \multicolumn{7}{|l|}{$\mathrm{BHBA}, \mathrm{mg} / \mathrm{dL}$} \\
\hline Prepartum & 8.9 & 9.1 & 9.7 & 0.3 & 0.08 & 0.54 \\
\hline Postpartum & 10.5 & 10.9 & 11.3 & 0.5 & 0.18 & 0.96 \\
\hline Peripartum & 9.6 & 9.9 & 10.2 & 0.3 & 0.04 & 0.90 \\
\hline \multicolumn{7}{|l|}{ Insulin, $\mathrm{ng} / \mathrm{mL}$} \\
\hline Prepartum & 1.12 & 1.32 & 1.27 & 0.09 & 0.16 & 0.20 \\
\hline Postpartum & 0.64 & 0.75 & 0.68 & 0.07 & 0.61 & 0.18 \\
\hline Peripartum & 0.80 & 0.94 & 0.90 & 0.07 & 0.15 & 0.16 \\
\hline
\end{tabular}

${ }^{1}$ Prepartum values represent data collected daily from $21 \mathrm{~d}$ through $1 \mathrm{~d}$ before parturition. Postpartum values represent data collected daily from parturition through $7 \mathrm{~d}$ postpartum and every $3 \mathrm{~d}$ from 10 through $21 \mathrm{~d}$ postpartum. Peripartum values represent data collected daily from $7 \mathrm{~d}$ before parturition through $7 \mathrm{~d}$ postpartum.

${ }^{2}$ Cows received a prepartum treatment of $0 \mathrm{mg}$ of TZD $/ \mathrm{kg}$ of BW $(\mathrm{n}=12), 2.0 \mathrm{mg}$ of TZD $/ \mathrm{kg}$ of BW $(\mathrm{n}=12)$, and $4.0 \mathrm{mg}$ of TZD $/ \mathrm{kg}$ of BW $(\mathrm{n}=12)$ from $21 \mathrm{~d}$ before expected parturition through parturition.

ates during analysis of covariance applied to their corresponding measurements during the treatment period. Analysis of variance was conducted on measurements conducted over time (plasma variables, DMI, BW, BCS, milk yield, and liver composition) using the MIXED procedure (SAS Institute, 2001) for a completely randomized design with repeated measures. The model included the fixed effects of covariate, treatment, time, and the interaction of treatment and time. Cows were blocked by expected calving date and block was included as a random effect along with cow nested within treatment. For each variable, cow was subjected to 7 covariance structures (first-order autoregressive, heterogeneous first-order autoregressive, compound symmetry, heterogeneous compound symmetry, first-order antedependence, Toeplitz, and variance components). The structure yielding the smallest Akaike's information criterion was selected. The method of KenwardRogers was used to calculate denominator degrees of freedom. Covariates were dropped from the model if $P>0.20$ and the data were reanalyzed. Prepartum (d -21 to -1 or wk -3 to -1 ), postpartum (d 0 to 21 or wk 1 to 9 , depending on the variable), and peripartum (d -7 to +7 ) data were analyzed separately. Measurements that were not repeated over time (e.g., calf birth weight, colostrum yield, IgG concentration, and days to first ovulation) were subjected to ANOVA using the MIXED procedure of SAS. The model included the effects of treatment. The number of cows with days to first ovulation less than or equal to $21 \mathrm{~d}$ was evaluated by chi-square analysis.

Linear and quadratic effects of increasing doses of TZD were evaluated using orthogonal contrasts for all variables measured. Statistical significance was declared at $P<0.05$ and trends were discussed at $0.05<$ $P<0.10$. Least squares means and SEM are reported throughout.

\section{RESULTS}

Overall plasma concentrations of plasma NEFA, BHBA, glucose, and insulin during the prepartum (d -21 to -1 relative to parturition), postpartum (d 0 to 21 postpartum), and peripartum ( $\mathrm{d}-7$ to +7 relative to parturition) periods are presented in Table 2 . Given the lack of treatment $\times$ time interactions for the variables measured, only overall effects are reported. Plasma NEFA concentrations (Table 2) were affected quadratically $(P=0.03)$ during the prepartum period such that cows administered $2.0 \mathrm{mg}$ of TZD $/ \mathrm{kg}$ of $\mathrm{BW}$ had higher NEFA than either control cows or cows administered $4.0 \mathrm{mg}$ of TZD $/ \mathrm{kg}$ of BW. Effects of prepartum TZD administration on peripartum NEFA concentrations were not significant; however, prepartum TZD administration resulted in linearly decreased $(P=0.04)$ plasma NEFA concentrations during the postpartum period. Prepartum administration of TZD resulted in quadratic relationships for plasma glucose concentrations such that cows administered $4.0 \mathrm{mg}$ of TZD $/ \mathrm{kg}$ 
Table 3. Least squares means for the effects of prepartum thiazolidinedione (TZD) treatment on liver composition

\begin{tabular}{|c|c|c|c|c|c|c|}
\hline Liver & \multicolumn{3}{|c|}{$\mathrm{TZD},{ }^{1} \mathrm{mg} / \mathrm{kg}$ of $\mathrm{BW}$} & $\mathrm{SE}$ & \multicolumn{2}{|c|}{$P$-value } \\
\hline Triglycerides, $\%$ wet wt & 11.0 & 10.4 & 4.2 & 1.6 & 0.007 & 0.17 \\
\hline Ratio, triglycerides:glycogen & 7.0 & 4.9 & 1.9 & 1.4 & 0.01 & 0.82 \\
\hline
\end{tabular}

${ }^{1}$ Cows received a prepartum treatment of $0 \mathrm{mg}$ of TZD $/ \mathrm{kg}$ of BW $(\mathrm{n}=12), 2.0 \mathrm{mg}$ of TZD $/ \mathrm{kg}$ of BW $(\mathrm{n}=12)$, and $4.0 \mathrm{mg}$ of TZD $/ \mathrm{kg}$ of BW $(\mathrm{n}=12)$ from $21 \mathrm{~d}$ before expected parturition through parturition.

of BW had increased plasma glucose (Table 2) during the postpartum period $(P<0.01)$ and tended $(P=$ $0.06)$ to have increased plasma glucose concentrations during the peripartum period. There was no effect $(P$ $>0.10)$ on prepartum plasma glucose concentrations. Plasma concentrations of BHBA tended $(P=0.08)$ to be increased linearly during the prepartum period with increasing TZD and were increased $(P=0.04)$ linearly during the peripartum period; however, concentrations of postpartum BHBA were not affected by prepartum treatment. There was no effect $(P>0.10)$ of prepartum TZD administration on prepartum, postpartum, or peripartum plasma concentrations of insulin (Table 2).

Liver composition from samples collected via biopsy on d 10 and 21 postpartum is described in Table 3. Administration of prepartum TZD linearly decreased $(P<0.01)$ liver TG concentrations and the ratio of liver TG to glycogen $(P=0.01)$, and linearly increased liver glycogen content $(P=0.02)$.

Overall effects of prepartum TZD administration on DMI, milk yield, milk composition, calculated net energy balance, BCS, BW, and parameters measured on the day of calving are reported in Table 4. Peripartum DMI was increased linearly $(P=0.04)$ for cows administered increasing amounts of TZD during the prepartum period, but there was no effect $(P>0.10)$ of prepartum TZD on prepartum or postpartum DMI. Administration of TZD during the prepartum period resulted in quadratic relationships for some production variables such that cows administered $4.0 \mathrm{mg}$ of TZD/ $\mathrm{kg}$ of BW generally produced less milk $(P=0.10)$, $3.5 \%$ FCM $(P=0.04)$, ECM $(P=0.05)$, milk fat $(P$ $=0.10)$, milk lactose $(P=0.09)$, and TS in milk $(P=$ 0.07). Milk fat and TS percentages were not affected by treatment; however, a quadratic relationship tended (0.06) to exist such that cows administered $2.0 \mathrm{mg}$ of TZD/kg of BW during the prepartum period had lower milk protein content. Prepartum TZD administration resulted in linearly increased $(P=0.04)$ milk lactose content. Effects on somatic cell linear score and milk urea $\mathrm{N}$ were not significant.

Prepartum TZD administration linearly increased $(P<0.03)$ prepartum calculated net energy balance, expressed both as megacalories per day and as a per- centage of requirements (Table 4). Postpartum calculated energy balance, expressed as megacalories per day, tended $(P=0.09)$ to be quadratically affected by prepartum TZD such that cows administered $4.0 \mathrm{mg}$ of TZD/kg of BW had higher calculated energy balance. Consistent with these calculations, cows administered increasing doses of TZD prepartum maintained higher $(P<0.01)$ BCS than control cows during the postpartum period (Figure 1). A treatment $\times$ week interaction existed $(P=0.03)$ for postpartum period such that cows administered either prepartum TZD dose maintained higher BCS than control cows during the first several weeks postpartum, but only cows administered $4.0 \mathrm{mg}$ of $\mathrm{TZD} / \mathrm{kg}$ of $\mathrm{BW}$ maintained higher BCS by the end of the experimental period.

Prepartum TZD administration did not affect calf birth weight or colostral IgG content. Colostrum yield was affected quadratically $(P=0.03)$ by prepartum TZD such that cows receiving $2.0 \mathrm{mg}$ of $\mathrm{TZD} / \mathrm{kg}$ of BW produced more colostrum than cows assigned to the other 2 treatments (Table 4 ).

Reproductive performance parameters are described in Table 5. Prepartum TZD administration linearly decreased $(P=0.02)$ days to first ovulation, but did not affect $(P=0.12)$ the proportion of cows ovulating by $21 \mathrm{~d}$ postpartum. There was no effect $(P>0.10)$ of prepartum treatment on peak plasma progesterone concentration, size of the dominant follicle, day postpartum of the peak dominant follicle size, or the size of the corpus luteum $(\mathbf{C L})$.

\section{DISCUSSION}

The development of insulin resistance in late pregnancy is an important adaptation that continues into early lactation to spare glucose for the gravid uterus and mammary gland (Bauman and Elliot, 1983; Bell, 1995). However, it is likely that prepartum insulin resistance also contributes to the concurrent acute increase in circulating NEFA and decrease in DMI that occurs during the last 7 to $10 \mathrm{~d}$ before parturition (Smith, 2004; Allen et al., 2005). This relationship appears to influence all periparturient health disorders with etiologies based on energy metabolism, immune function, or both. 
Table 4. Least squares means for the effects of prepartum thiazolidinedione (TZD) treatment on production variables

\begin{tabular}{|c|c|c|c|c|c|c|}
\hline \multirow[b]{2}{*}{ Item } & \multicolumn{3}{|c|}{$\mathrm{TZD},{ }^{1} \mathrm{mg} / \mathrm{kg}$ of $\mathrm{BW}$} & \multirow[b]{2}{*}{$\mathrm{SE}$} & \multicolumn{2}{|c|}{$P$-value } \\
\hline & 0 & 2.0 & 4.0 & & Linear & Quadratic \\
\hline \multicolumn{7}{|l|}{ DMI, $\mathrm{kg} / \mathrm{d}$} \\
\hline Prepartum ${ }^{2}$ & 14.4 & 14.7 & 15.1 & 0.5 & 0.26 & 0.92 \\
\hline Postpartum ${ }^{3}$ & 24.0 & 24.8 & 24.0 & 0.6 & 0.93 & 0.29 \\
\hline Peripartum $^{4}$ & 16.1 & 17.2 & 17.3 & 0.5 & 0.05 & 0.31 \\
\hline Milk yield ${ }^{5} \mathrm{~kg} / \mathrm{d}$ & 50.1 & 52.1 & 46.6 & 1.9 & 0.18 & 0.10 \\
\hline $3.5 \% \mathrm{FCM},{ }^{6} \mathrm{~kg} / \mathrm{d}$ & 52.2 & 54.6 & 48.0 & 1.6 & 0.10 & 0.04 \\
\hline $\mathrm{ECM},{ }^{7} \mathrm{~kg} / \mathrm{d}$ & 51.7 & 53.6 & 48.0 & 1.6 & 0.10 & 0.05 \\
\hline Fat, ${ }^{3} \%$ & 3.90 & 3.88 & 3.90 & 0.11 & 0.95 & 0.86 \\
\hline Fat, $\mathrm{kg} / \mathrm{d}$ & 1.88 & 1.98 & 1.73 & 0.06 & 0.03 & 0.10 \\
\hline True protein, ${ }^{3} \%$ & 3.13 & 3.01 & 3.18 & 0.07 & 0.60 & 0.06 \\
\hline True protein, kg/d & 1.52 & 1.53 & 1.42 & 0.05 & 0.20 & 0.30 \\
\hline Lactose, ${ }^{3} \%$ & 4.68 & 4.69 & 4.77 & 0.05 & 0.04 & 0.25 \\
\hline Lactose, $\mathrm{kg} / \mathrm{d}$ & 2.36 & 2.45 & 2.22 & 0.08 & 0.21 & 0.09 \\
\hline $\mathrm{TS}^{3} \%$ & 12.6 & 12.5 & 12.8 & 0.2 & 0.41 & 0.18 \\
\hline $\mathrm{TS}, \mathrm{kg} / \mathrm{d}$ & 6.20 & 6.44 & 5.81 & 0.19 & 0.16 & 0.07 \\
\hline SCC linear score ${ }^{8}$ & 2.04 & 2.29 & 2.03 & 0.45 & 0.98 & 0.37 \\
\hline $\mathrm{MUN},{ }^{3} \mathrm{mg} / \mathrm{dL}$ & 13.8 & 13.8 & 13.1 & 0.4 & 0.22 & 0.42 \\
\hline \multicolumn{7}{|l|}{ Energy balance ${ }^{9}$} \\
\hline Prepartum, ${ }^{2} \mathrm{Mcal} / \mathrm{d}$ & 7.6 & 8.3 & 9.2 & 0.6 & 0.03 & 0.85 \\
\hline Prepartum, ${ }^{2} \%$ of requirements & 150 & 154 & 162 & 4 & 0.01 & 0.63 \\
\hline Postpartum, ${ }^{5} \mathrm{Mcal} / \mathrm{d}$ & -4.9 & -5.8 & -2.6 & 1.0 & 0.11 & 0.09 \\
\hline Postpartum,, 5 of requirements & 90 & 88 & 95 & 2 & 0.20 & 0.19 \\
\hline \multicolumn{7}{|l|}{ BCS $^{10}$} \\
\hline Prepartum & 3.28 & 3.37 & 3.34 & 0.03 & 0.14 & 0.12 \\
\hline Postpartum & 2.77 & 2.89 & 3.02 & 0.05 & 0.001 & 0.88 \\
\hline \multicolumn{7}{|l|}{$\mathrm{BW}, \mathrm{kg}$} \\
\hline Prepartum & 739 & 748 & 745 & 4 & 0.33 & 0.19 \\
\hline Postpartum & 664 & 671 & 681 & 8 & 0.11 & 0.89 \\
\hline Calf birth weight, ${ }^{11} \mathrm{~kg}$ & 46 & 46 & 43 & 1 & 0.22 & 0.33 \\
\hline Colostrum, $\mathrm{kg}$ & 5.5 & 8.0 & 4.7 & 1.0 & 0.54 & 0.03 \\
\hline $\mathrm{IgG}, \mathrm{mg} / \mathrm{mL}$ & 104 & 109 & 111 & 13 & 0.64 & 0.92 \\
\hline
\end{tabular}

${ }^{1}$ Cows received a prepartum treatment of $0 \mathrm{mg}$ of TZD $/ \mathrm{kg}$ of BW $(\mathrm{n}=12), 2.0 \mathrm{mg}$ of TZD $/ \mathrm{kg}$ of BW $(\mathrm{n}=12)$, and $4.0 \mathrm{mg}$ of TZD $/ \mathrm{kg}$ of BW $(\mathrm{n}=12)$ from $21 \mathrm{~d}$ before expected parturition through parturition.

${ }^{2}$ Represents data collected daily from $21 \mathrm{~d}$ through $1 \mathrm{~d}$ before parturition.

${ }^{3}$ Represents data collected weekly from wk 1 through 9 postpartum.

${ }^{4}$ Represents data collected daily from $7 \mathrm{~d}$ before parturition through $7 \mathrm{~d}$ postpartum.

${ }^{5}$ Represents milk yields collected daily from parturition through $63 \mathrm{~d}$ postpartum and then averaged for each week postpartum.

${ }^{6} 3.5 \% \mathrm{FCM}=(0.4324 \times \mathrm{kg}$ of milk $)+(16.216 \times \mathrm{kg}$ of milk fat $)$.

${ }^{7} \mathrm{ECM}=[(0.327 \times \mathrm{kg}$ of milk $)+(12.95 \times \mathrm{kg}$ of fat $)+(7.2 \times \mathrm{kg}$ of protein $)]$.

${ }^{8}$ Calculated according to Schroeder (1997).

${ }^{9}$ Calculated as net energy balance according to NRC (2001).

${ }^{10}$ Five-point scale (Wildman et al., 1982).

${ }^{11}$ Cows treated with $0 \mathrm{mg}$ of TZD $/ \mathrm{kg}$ of BW had 8 females and 6 males from 13 cows $(1$ set of twin females was removed from the data set before analysis) and all calves were born alive; cows treated with $2.0 \mathrm{mg}$ of TZD $/ \mathrm{kg}$ of BW had 2 females, 10 males and 1 calf of neither sex, which was born dead, from 13 cows; cows treated with $4.0 \mathrm{mg}$ of TZD $/ \mathrm{kg}$ of BW had 3 females and 13 males from 14 cows $(2$ sets of twin males were removed from the data set before analysis), and all calves were born alive. Average days over or under the due date $=0$.

We expect that some aspects of insulin resistance in adipose tissue are mediated through the action of PPAR- $\gamma$ in dairy cows during the transition period. Thiazolidinediones are potent synthetic ligands for PPAR- $\gamma$ that have been shown to reduce plasma NEFA and potentiate the action of insulin in peripheral tissues of several species (Houseknecht et al., 2002; Hammarstedt et al., 2005; Guo and Tabrizchi, 2006).
Peroxisome proliferator-activated receptor- $\gamma$ is highly expressed in adipose tissue in both lactating (Harvatine and Bauman, 2007) and nonlactating (Sundvold et al., 1997) bovines, and we expect that TZD administration would directly activate PPAR- $\gamma$ in adipose tissue. Few studies have been published in which TZD was administered to ruminants. We recently demonstrated that TZD administration to late prepartum dairy cows 
Table 5. Reproductive performance during the transition period and early lactation

\begin{tabular}{|c|c|c|c|c|c|c|}
\hline \multirow[b]{2}{*}{ Item } & \multicolumn{3}{|c|}{$\mathrm{TZD},{ }^{1} \mathrm{mg} / \mathrm{kg}$ of $\mathrm{BW}$} & \multirow[b]{2}{*}{$\mathrm{SE}$} & \multicolumn{2}{|c|}{$P$-value } \\
\hline & 0 & 2.0 & 4.0 & & Linear & Quadratic \\
\hline First ovulation, d & 29.3 & 28.3 & 19.0 & 3.6 & 0.02 & 0.24 \\
\hline Peak progesterone, ng/mL & 9.2 & 10.1 & 8.5 & 0.8 & 0.50 & 0.19 \\
\hline First ovulation $\leq 21 \mathrm{~d}, \mathrm{n} /$ group & $3 / 12$ & $8 / 12$ & $6 / 12$ & - & 0.12 & - \\
\hline Peak follicle diameter, $\mathrm{mm}^{2}$ & 19.4 & 19.2 & 19.2 & 3.2 & 0.65 & 0.82 \\
\hline Day postpartum peak follicle ${ }^{2}$ & 14.0 & 14.6 & 12.4 & 1.7 & 0.44 & 0.42 \\
\hline Corpus luteum size, $\mathrm{mm}^{2}$ & 21.0 & 22.2 & 21.0 & 4.1 & 0.85 & 0.87 \\
\hline
\end{tabular}

${ }^{1}$ Cows received a prepartum treatment of $0 \mathrm{mg}$ of TZD $/ \mathrm{kg}$ of $\mathrm{BW}(\mathrm{n}=12), 2.0 \mathrm{mg}$ of TZD $/ \mathrm{kg}$ of $\mathrm{BW}(\mathrm{n}=12)$, and $4.0 \mathrm{mg}$ of TZD/kg of BW $(\mathrm{n}=12)$ from $21 \mathrm{~d}$ before expected parturition through parturition.

${ }^{2}$ Ovarian ultrasonography measurements 3 times per week from $7 \mathrm{~d}$ postpartum through $21 \mathrm{~d}$ postpartum.

tended to reduce plasma NEFA and tended to increase DMI during the peripartum ( $\mathrm{d}-7$ to $\mathrm{d}+7)$ period (Smith et al., 2007).

In this experiment, the effects of TZD administration on plasma NEFA concentrations were similar to those reported in our previous experiment (Smith et al., 2007). Daily administration of TZD during the prepartum period linearly decreased plasma NEFA concentrations from d 7 prepartum through d 7 postpartum. In the only other published experiment using TZD in ruminants, Kushibiki et al. (2001) administered recombinant TNF- $\alpha$ to steers for $9 \mathrm{~d}$ to induce insulin resistance and increase plasma NEFA. Similar to the current and previously reported results in transition dairy cows, administration of $2.0 \mathrm{mg}$ of TZD $/ \mathrm{kg}$ of $\mathrm{BW}$ to recombinant $\mathrm{TNF}-\alpha$-treated animals significantly reduced plasma NEFA after d 2 of treatment. Reduction of plasma NEFA concentrations is a consistent observation across many large-scale TZD clinical studies in humans or laboratory animals, and these results are consistent with PPAR- $\gamma$ activation (as reviewed by Sharma and Staels, 2007).

Tordjman et al. (2003) reported that TZD directly stimulates reesterification of fatty acids in adipocytes and lowers fatty acid release into the plasma by inducing phosphoenolpyruvate carboxykinase in adipose tissue, which increases glyceroneogenesis and promotes a futile cycle; however, the activity of phosphoenolpyruvate carboxykinase and its activation by TZD in bovine adipose is unknown. Most likely, the small increases in plasma glucose during the peripartum and postpartum periods in cows administered $4.0 \mathrm{mg}$ of $\mathrm{TZD} / \mathrm{kg}$ of BW

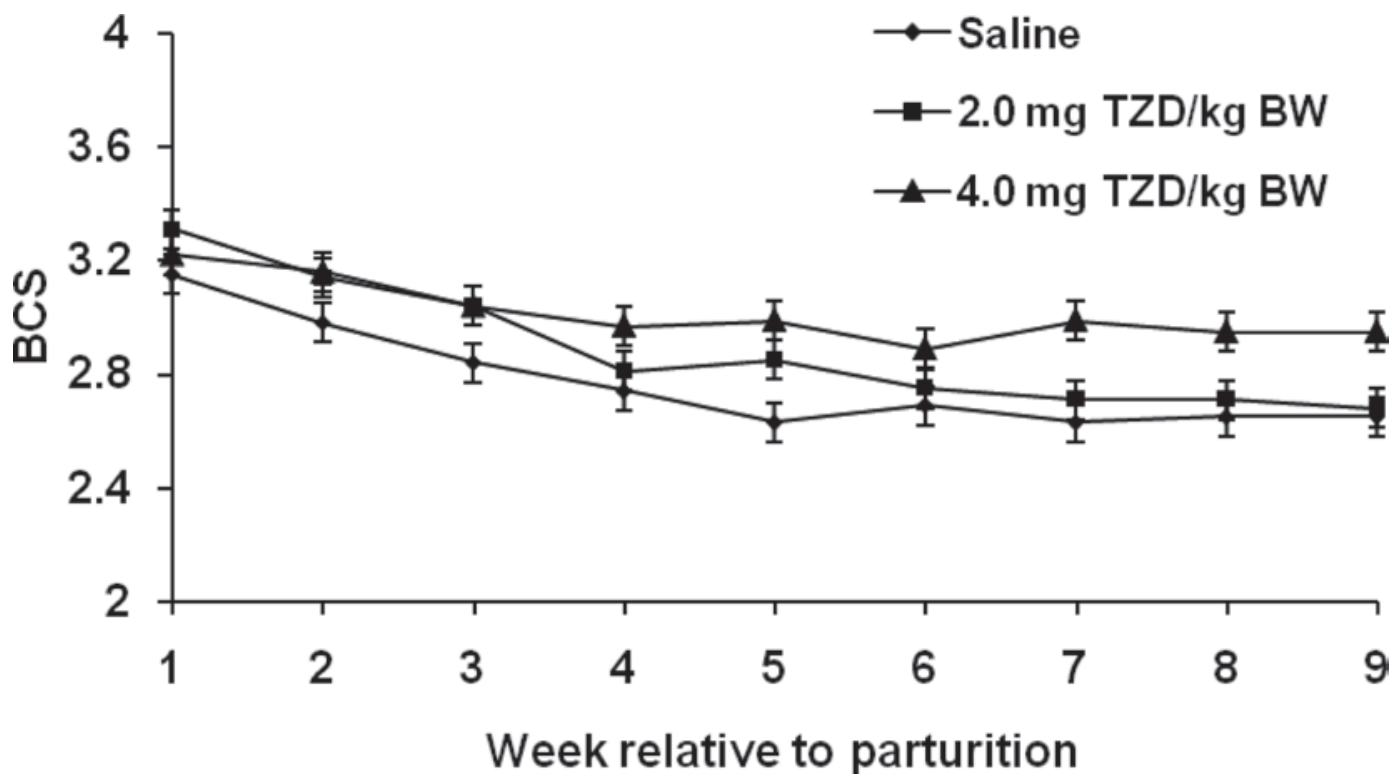

Figure 1. Postpartum BCS of cows administered increasing amounts of thiazolidinedione (TZD) during the prepartum period. Values are least squares means, with error bars representing the SEM; $\mathrm{n}=12$ for saline, $\mathrm{n}=12$ for $2.0 \mathrm{mg}$ of TZD/ $\mathrm{kg}$ of $\mathrm{BW}$, and $\mathrm{n}=12 \mathrm{for} 4.0 \mathrm{mg}$ of TZD $/ \mathrm{kg}$ of BW. The $P$-value for the overall linear effect of TZD was $<0.001$, the $P$-value for the overall quadratic effect of TZD was 0.88 , and the $P$-value for the interaction of treatment and week was 0.03 . 
in the late prepartum period can be explained by the downstream effects of TZD administration on liver TG concentrations. Accumulation of TG in the liver decreases the hepatic gluconeogenic capacity (Bobe et al., 2004; Overton and Waldron, 2004). Therefore, cows administered $4.0 \mathrm{mg}$ of $\mathrm{TZD} / \mathrm{kg}$ of BW may have had increased gluconeogenic capacity in the liver.

Consistent with the decrease in plasma NEFA concentrations during the peripartum and postpartum periods for cows treated with TZD during the prepartum period, liver TG content was linearly decreased by increasing TZD administration prepartum. It has been demonstrated that cows with decreased plasma NEFA concentrations typically have lower liver TG concentrations (Drackley et al., 2001). Thiazolidinediones such as pioglitazone and rosiglitazone have consistently been shown to reduce hepatic TG content in humans with type 2 diabetes (Mayerson et al., 2002; Bajaj et al., 2003). Higher uptake of fatty acids by adipose tissue might have reduced their delivery to the liver, thus decreasing hepatic TG content. In addition, in the current study TZD administration linearly increased liver glycogen stores. Although this increase is consistent with an increase in plasma glucose concentrations during the peripartum period, the small increase in liver glycogen content is confounded with the large decrease in liver TG content. This decrease in liver TG and increase in liver glycogen resulted in a decreased liver TG-toglycogen ratio in cows administered TZD prepartum. This ratio has been suggested to be an indicator for the likelihood of a cow to develop ketosis (Drackley et al., 1992). In the current experiment, prepartum TZD tended to increase plasma BHBA concentrations during the prepartum period and increased peripartal BHBA concentrations, although the magnitude of the increase was small. We previously reported (Smith et al., 2007) that BHBA concentrations in cows administered TZD were decreased as parturition approached. Cows in our previous experiment were feed restricted to consume no more than $130 \%$ of calculated energy requirements during the prepartum period, whereas cows in the present experiment were fed for ad libitum intake during this time frame and consumed approximately $150 \%$ of the calculated energy requirements. These differences in energy intake likely were relatively minor; therefore, the reason for the differences in results between experiments is not clear.

Dry matter intake increased linearly with TZD dose during the peripartum period, consistent with results of our previous experiment (Smith et al., 2007). This could again have been attributed to the reduction in postpartum plasma NEFA concentrations (Allen et al., 2005); however, there could have been a direct or a carryover effect of prepartum TZD administration on peripartum DMI. Activation of PPAR- $\gamma$ by TZD administration has been shown to increase food intake in normal, aging, and Zucker diabetic rats (WoldenHanson et al., 2002; Larsen et al., 2003; Saitoh et al., 2007). Administration of TZD as rosiglitazone to healthy men housed in respiration chambers increased energy balance and energy intake (Joosen et al., 2006). Humans treated for type 2 diabetes with troglitazone have reported increases in hunger when compared with patients not administered TZD (Shimizu et al., 1998). In addition, TZD has been shown to reduce TNF- $\alpha$ mRNA expression and plasma TNF- $\alpha$ levels in humans (as reviewed by Hammarstedt et al., 2005). Expression of mRNA for TNF- $\alpha$ is elevated in liver (Loor et al., 2005) and possibly adipose tissue at the onset of parturition. Given that TNF- $\alpha$ administration has been reported to reduce feed intake in lactating dairy cows (Kushibiki et al., 2003), it is possible that TZD-induced positive changes in DMI during the peripartum period may have been mediated by decreased expression of TNF- $\alpha$, but this was not measured in the present study. The increase in peripartum DMI was most likely due to a combination of the reduction in plasma NEFA and the direct effects of activation of PPAR- $\gamma$.

One of the objectives of this experiment was to follow up our previous experiment with a larger scale study, in part to examine the effects of TZD administration on aspects of performance during the postpartum period. Previously, milk production was not affected by prepartum TZD administration (Smith et al., 2007). In the current experiment, milk production during the first 63 d postpartum tended to be decreased and yields of $3.5 \%$ FCM were reduced $(P=0.04)$ in cows administered 4.0 $\mathrm{mg}$ of $\mathrm{TZD} / \mathrm{kg}$ of $\mathrm{BW}$ during the prepartum period. These results are consistent with the concurrent linear reduction in peripartum plasma NEFA concentrations that would be available for direct incorporation into milk fat. In general, yields of milk components were decreased for cows administered $4.0 \mathrm{mg}$ of TZD $/ \mathrm{kg}$ of BW during the prepartum period. Reasons for differences in results between the 2 experiments are uncertain; however, performance effects also should be evaluated in which TZD is able to be administered without chronic catheterization and intensive handling. There are no previous reports on the effects of TZD on milk yield in any species, and the experiments conducted in our laboratory are the first reported.

Although the limited replication in this experiment did not allow for comprehensive evaluation of the reproductive performance of cows administered TZD during the prepartum period, we evaluated days to first ovulation indirectly based on plasma progesterone and several aspects of follicular dynamics. Administration of prepartum TZD linearly decreased the number of 
days to first ovulation. Negative energy balance has been shown to have a negative impact on the timing of postpartum first ovulation (Butler, 2000; Jorritsma et al., 2003) and minimizing BCS loss has been shown to optimize reproductive efficiency (as reviewed by Roche, 2006). In this study, prepartum TZD administration tended to increase postpartum net energy balance quadratically and resulted in less loss $(P<0.01)$ of BCS postpartum. These results suggest that improved energy balance after TZD administration in dairy cows may improve reproductive performance. Furthermore, higher BCS during early lactation for cows administered TZD prepartum corroborates the positive effects of prepartum TZD administration on postpartum calculated net energy balance. Despite these effects on days to first ovulation, prepartum TZD administration did not affect the size or day of the dominant follicle or the size of the CL. Lucy et al. (1991) reported that the predicted energy balance before d 25 postpartum was not related to the frequency of class $4(>15 \mathrm{~mm})$ follicles. Beam and Butler (1997) determined that cows fed increasing amounts of added fat during early lactation had more class 4 follicles by d 14 postpartum; however, the number of large follicles was not correlated with energy balance in their study. Clearly, aspects of reproduction as potentially affected by prepartum TZD warrant more thorough investigation in a larger study.

There was no effect of prepartum TZD administration on calf birth weight in the present or previous (Smith et al., 2007) experiment. Sevillano et al. (2005) reported that newborn rats from mothers treated with TZD as englitazone had a lower body mass than control rats, but the size of the litter was not changed. In that study, mothers were treated with TZD for 4 out of the $20 \mathrm{~d}$ they were pregnant, or $20 \%$ of the pregnancy. Our cows were treated for 21 or $25 \mathrm{~d}$ (Smith et al., 2007) of the $280 \mathrm{~d}$ they were pregnant, or about 7.5 or $9 \%$ of their pregnancy, respectively. It is possible that the TZD was not administered to the cows long enough for there to be an effect on calf birth weight. However, a second experiment was recently published in which rosiglitazone was administered during the entire pregnancy and showed that postnatal growth and litter size in mice were unaffected by treatment; the authors concluded that prepartum TZD caused no phenotypic harm to the mouse fetus, suggesting potential safety of use during pregnancy (Klinkner et al., 2006). Finally, colostrum quantity was increased by prepartum administration of $2.0 \mathrm{mg}$ of TZD/ $\mathrm{kg}$ of BW; however, quality as assessed by IgG content appeared to be uniformly high and sufficient across all treatments (Davis and Drackley, 1998).

\section{CONCLUSIONS}

Administration of TZD during the prepartum period linearly decreased plasma NEFA concentrations during the postpartum period and linearly increased DMI during the peripartum period, consistent with our previous findings (Smith et al., 2007). Cows administered increasing amounts of TZD during the prepartum period had decreased liver TG postpartum, higher BCS through the 9-wk postpartum period, and decreased days to first ovulation compared with control cows, suggesting the potential for favorable effects of prepartum TZD administration on aspects of health and reproduction, although replication with a larger experiment will be required to further define effects on both health disorder incidence and reproductive performance.

\section{ACKNOWLEDGMENTS}

The assistance of the following colleagues and students at Cornell University in implementing the study is gratefully acknowledged and appreciated: D. Dwyer, R. Watters, J. W. Perfield II, R. Ehrhardt, S. Pelton, M. Hurley, J. Lukas, K. Ward, J. M. Ramos-Nieves, J. Hillegass, S. Pelton, and the staff at the Cornell University Dairy Teaching and Research Center.

\section{REFERENCES}

Allen, M. S., B. J. Bradford, and K. J. Harvatine. 2005. The cow as a model to study food intake regulation. Annu. Rev. Nutr. 25:523-547.

Bajaj, M., S. Suraamornkul, T. Pratipanawatr, L. J. Hardies, W. Pratipanawatr, L. Glass, E. Cersosimo, Y. Miyazaki, and R. A. DeFronzo. 2003. Pioglitazone reduces hepatic fat content and augments splanchnic glucose uptake in patients with type 2 diabetes. Diabetes 52:1364-1370.

Bauman, D. E., and W. B. Currie. 1980. Partitioning of nutrients during pregnancy and lactation: A review of mechanisms involving homeostasis and homeorhesis. J. Dairy Sci. 63:1514-1529.

Bauman, D. E., and J. M. Elliot. 1983. Control of nutrient partitioning in lactating ruminants. Pages 437-468 in Biochemistry of Lactation. T. B. Mepham, ed. Elsevier Science Publishers, Amsterdam, the Netherlands.

Beam, S. W., and W. R. Butler. 1997. Energy balance and ovarian follicle development prior to the first ovulation postpartum in dairy cows receiving three levels of dietary fat. Biol. Reprod. 56:133-142.

Bell, A. W. 1995. Regulation of organic nutrient metabolism during transition from late pregnancy to early lactation. J. Anim. Sci. 73:2804-2819.

Bobe, G., J. W. Young, and D. C. Beitz. 2004. Invited review: Pathology, etiology, prevention, and treatment of fatty liver in dairy cows. J. Dairy Sci. 87:3105-3124.

Butler, W. R. 2000. Nutritional interactions with reproductive performance in dairy cattle. Anim. Reprod. Sci. 60-61:449-457.

Davis, C. L., and J. K. Drackley. 1998. The Development, Nutrition, and Management of the Young Calf. Iowa State University Press, Ames. 
Drackley, J. K., T. R. Overton, and G. N. Douglas. 2001. Adaptations of glucose and long-chain fatty acid metabolism in liver of dairy cows during the periparturient period. J. Dairy Sci. 84(E Suppl.):E100-E112.

Drackley, J. K., M. J. Richard, D. C. Beitz, and J. W. Young. 1992. Metabolic changes in dairy cows with ketonemia in response to feed restriction and dietary 1,3-butanediol. J. Dairy Sci. 75:16221634 .

Ehrhardt, R. A., R. M. Slepetis, A. W. Bell, and Y. R. Boisclair. 2001. Maternal leptin is elevated during pregnancy in sheep. Domest. Anim. Endocrinol. 21:85-96.

Guo, L., and R. Tabrizchi. 2006. Peroxisome proliferator-activated receptor gamma as a drug target in the pathogenesis of insulin resistance. Pharmacol. Ther. 111:145-173.

Hammarstedt, A., C. X. Andersson, V. Rotter Sopasakis, and U. Smith. 2005. The effect of PPAR- $\gamma$ ligands on the adipose tissue in insulin resistance. Prostaglandins Leukot. Essent. Fatty Acids 73:65-75.

Harvatine, K. J., and D. E. Bauman. 2007. Expression of PPAR and LXR nuclear hormone receptor families are not modified during milk fat depression induced by diet or treatment with trans-10, cis-12 conjugated linoleic acid (CLA). J. Dairy Sci. 90(Suppl. 1):59. (Abstr.)

Houseknecht, K. L., B. M. Cole, and P. J. Steele. 2002. Peroxisome proliferator-activated receptor gamma (PPARgamma) and its ligands: A review. Domest. Anim. Endocrinol. 22:1-23.

Joosen, A. M. C. P., A. H. F. Bakker, M. J. A. Gering, and K. R. Westerterp. 2006. The effect of PPAR $\gamma$ ligand rosiglitazone on energy balance regulation. Diabetes Metab. Res. Rev. 22:204210.

Jorritsma, R., T. Wensing, T. A. M. Kruip, P. L. A. M. Vos, and P. T. M. Noordhuizen. 2003. Metabolic changes in early lactation and impaired reproductive performance in dairy cows. Vet. Res. $34: 11-26$.

Klinkner, D. B., H. J. Lim, E. Y. Strawn, K. T. Oldham, and T. L. Sander. 2006. An in vivo murine model of rosiglitazone use in pregnancy. Fertil. Steril. 86:1074-1079.

Kushibiki, S., K. Hodate, H. Shingu, Y. Obara, E. Touno, M. Shinoda, and Y. Yokomizo. 2003. Metabolic and lactational responses during recombinant bovine tumor necrosis factor- $\alpha$ treatment in lactating cows. J. Dairy Sci. 86:819-827.

Kushibiki, S., K. Hodate, H. Shingu, Y. Ueda, M. Shinoda, Y. Mori, T. Itoh, and Y. Yokomizo. 2001. Insulin resistance induced in dairy steers by tumor necrosis factor alpha is partially reversed by 2,4-thiazolidinedione. Domest. Anim. Endocrinol. 21:25-37.

Larsen, P. J., P. B. Jensen, R. V. Sørensen, L. K. Larsen, N. Vrang, E. M. Wulff, and K. Wassermann. 2003. Differential influences of peroxisome proliferator-activated receptors- $\gamma$ and $-\alpha$ on food intake and energy homeostasis. Diabetes 52:2249-2259.

Loor, J. J., H. M. Dann, R. E. Everts, R. Oliveira, C. A. Green, N. A. Janovick Guretzky, S. L. Rodriguez-Zas, H. A. Lewin, and J. K. Drackley. 2005. Temporal gene expression profiling of liver from periparturient dairy cows reveals complex adaptive mechanisms in hepatic function. Physiol. Genomics 23:217-226.

Lucy, M. C., C. R. Staples, F. M. Michel, and W. W. Thatcher. 1991. Energy balance and size and number of ovarian follicles detected by ultrasonography in early postpartum dairy cows. J. Dairy Sci. $74: 473-482$.

Mayerson, A. B., R. S. Hundal, S. Dufour, V. Lebon, D. Befroy, G. W. Cline, S. Enocksson, S. E. Inzucchi, G. I. Shulman, and K. F. Petersen. 2002. The effects of rosiglitazone on insulin sensitivity, lipolysis, and hepatic and skeletal muscle triglyceride content in patients with type 2 diabetes. Diabetes 51:797-802.

McNamara, J. P. 1991. Regulation of adipose tissue metabolism in support of lactation. J. Dairy Sci. 74:706-719.

Nara, B. S., and N. L. First. 1981. Effect of indomethacin and prostaglandin $\mathrm{F}_{2 \alpha}$ on parturition in swine. J. Anim. Sci. 52:13601370 .

NRC. 2001. Nutrient Requirements of Dairy Cattle. 7th rev. ed. Natl. Acad. Press, Washington, DC.
Overton, T. R., and M. R. Waldron. 2004. Nutritional management of transition dairy cows: Strategies to optimize metabolic health. J. Dairy Sci. 87(E Suppl.):E105-E119.

Petterson, J. A., F. R. Dunshea, R. A. Ehrhardt, and A. W. Bell. 1993. Pregnancy and undernutrition alter glucose metabolic responses to insulin in sheep. J. Nutr. 123:1286-1295.

Petterson, J. A., R. Slepetis, R. A. Ehrhardt, F. R. Dunshea, and A. W. Bell. 1994. Pregnancy but not moderate undernutrition attenuates insulin suppression of fat mobilization in sheep. J. Nutr. 124:2431-2436.

Pires, J. A. A., A. H. Souza, and R. R. Grummer. 2007. Induction of hyperlipidemia by intravenous infusion of tallow emulsion causes insulin resistance in Holstein cows. J. Dairy Sci. 90:2735-2744.

Reynolds, C. K., P. C. Aikman, B. Lupoli, D. J. Humphries, and D. E. Beever. 2003. Splanchnic metabolism of dairy cows during the transition from late gestation through early lactation. J. Dairy Sci. $86: 1201-1217$.

Roche, J. F. 2006. The effect of nutritional management of the dairy cow on reproductive efficiency. Anim. Reprod. Sci. 96:282-296.

Saitoh, Y., R. Liu, H. Ueno, M. Mizuta, and M. Nakazato. 2007. Oral pioglitazone administration increases food intake through ghrelinindependent pathway in Zucker fatty rat. Diabetes Res. Clin. Pract. 77:351-356.

SAS Institute. 2001. SAS User's Guide: Statistics, Version 8 Edition. SAS Inst. Inc., Cary, NC.

Schroeder, J. W. 1997. Mastitis control programs: Bovine mastitis and milking management. Fact sheet AS-1129, North Dakota State University. http://www.ag.ndsu.edu/pubs/ansci/dairy/as1129w. htm Accessed Oct. 21, 2008.

Sevillano, J., I. C. Lopez-Perez, E. Herrera, M. Del Pilar Ramos, and C. Bocos. 2005. Englitazone administration to late pregnant rats produces delayed body growth and insulin resistance in their fetuses and neonates. Biochem. J. 389:913-918.

Sharma, A. M., and B. Staels. 2007. Peroxisome proliferator-activated receptor $\gamma$ and adipose tissue-Understanding obesity-related changes in regulation of lipid and glucose metabolism. J. Clin. Endocrinol. Metab. 92:386-395.

Shimizu, H., T. Tsuchiya, N. Sato, Y. Shimomura, I. Kobayashi, and M. Mori. 1998. Troglitazone reduces plasma leptin concentration but increases hunger in NIDDM patients. Diabetes Care 21:1470 1474 .

Smith, K. L. 2004. Effects of prepartum carbohydrate source and chromium supplementation in dairy cows during the periparturient period. MS Thesis. Cornell Univ., Ithaca, NY.

Smith, K. L., S. E. Stebulis, M. R. Waldron, and T. R. Overton. 2007. Prepartum 2,4-thiazolidinedione alters metabolic dynamics and dry matter intake of dairy cows. J. Dairy Sci. 90:3660-3670.

Staigmiller, R. B., R. E. Short, R. A. Bellows, and J. B. Carr. 1979. Effect of nutrition on response to exogenous FSH in beef cattle. J. Anim. Sci. 48:1182-1190.

Sundvold, H., A. Brzozowska, and S. Lien. 1997. Characterisation of bovine peroxisome proliferator-activated receptors gamma 1 and gamma 2: Genetic mapping and differential expression of the two isoforms. Biochem. Biophys. Res. Commun. 239:857-861.

Tordjman, J., G. Chauvet, J. Quette, E. G. Beale, C. Forest, and B. Antoine. 2003. Thiazolidinediones block fatty acid release by inducing glyceroneogenesis in fat cells. J. Biol. Chem. 278:1878518790 .

Vernon, R. G. 2005. Lipid metabolism during lactation: A review of adipose tissue-liver interactions and the development of fatty liver. J. Dairy Res. 72:460-469.

Wildman, E. E., G. M. Jones, P. E. Wagner, R. L. Bowman, H. F. Trout, and T. N. Lesch. 1982. A dairy cow body condition scoring system and its relationship to selected production variables in high producing Holstein dairy cattle. J. Dairy Sci. 65:495-501.

Wolden-Hanson, T., B. T. Marck, and A. M. Matsumoto. 2002. Troglitazone treatment of aging Brown Norway rats improves food intake and weight gain after fasting without increasing hypothalamic NPY gene expression. Exp. Gerontol. 37:679-691. 